\title{
Lexical Eclecticism of Latin Texts on the Territory of Ukraine of the XV-XVII Centuries
}

\author{
Valentyna Myronova \& Nataliia Korolova \& Oksana Koshchii \\ (Taras Shevchenko National University of Kyiv)
}

\begin{abstract}
The article explores changes in the lexical system of the Latin language that have resulted from the close long-term interaction of several linguistic cultures. Latin was a spoken language which was under the influence and at the same time itself influenced other national European languages. As a result, the Latin language of one time period in different geographical areas had certain peculiarities. Particularly interesting is the example of Ukrainian version of Latin because it was used in Ukraine simultaneously with a language of another group with its own grammatical system and lexical composition. Despite the fact that Latin in Ukraine of the XVXVII centuries inherited grammatical and lexical systems of classical Latin, the level of which among the authors was rather high, the Latin language underwent certain changes due to the influence of Ukrainian and Polish.
\end{abstract}

\section{Keywords}

Latin language; lexical system of Latin; interlingual interference 


\section{Introduction}

The parallel existence of Ukrainian and Latin written traditions in corresponding spheres of social life in Ukraine $^{1}$ of the XV-XVII centuries is a historically conditioned phenomenon of Ukrainian culture. Latin was traditionally used in the judicial-administrative system, it was the language of education, culture and science, as well as the language of church use. The proposed study is devoted to the discovery of interference processes in the lexical system of Latin language on the territories of Ukraine of the $\mathrm{XV}-\mathrm{XVII}$ centuries, that appeared as a result of the long-term close interaction of several linguistic cultures. The relevance of our research is motivated by the absence of specific comprehensive studies on this issue, since domestic and foreign linguists and historians have previously analyzed only certain aspects of Latin language of the specified period.

The first one who drew attention to the existence of certain peculiarities of medieval Latin was the German medieval scholar K. Strecker. In one of the sections of his study, "Einführung in das Mittellatein" (1939), devoted to issues of medieval culture and literature, he noted some characteristic features of medieval Latin at the lexical and syntactic levels.

Both domestic and foreign researchers devoted a range of studies to phonetic, grammatical and lexical peculiarities of medieval Latin, such as: L. Dorovskih (1987; 1997), D. Drboglav (1993), M. Evans (1995), K. Langosch (1995), P. Lehmann (1911), F. Lutska-Lytvyak (1960), J. Marouzeau (1922-1953; 1943), D. Norberg (1959; 1980), P. Stotz (1996-2004) and others.

There are also many studies in Polish linguistics, which examine different aspects of medieval Latin. The works of the modern Polish medieval scholars: J. Axer (1991; 1995) and K. Weyssenhoff-Brożkowa (1998) greatly contribute to the understanding of the grammatical structure of medieval Latin. The work of the Polish scholar Studia nad tacina średniowieczna $w$ Polsce is the most comprehensive study on phonetic and morphological description as well as characteristics of the territorially close to us Polish medieval Latin.

Equally important are the studies of Czech classical linguists, among which it is worth mentioning the works of J. Nechutová (2002) and A. Vidmanová (1969).

Some details of the grammar of medieval Latin on the Scandinavian territories can be found in the work of Swedish scholar M. Hammarström (1925). On the basis of Latin documents from the territory of Sweden and Finland, M. Hammarström not only created the dictionary of medieval Latin, but in the preface also presented a rather comprehensive description of its phonetic-morphological features.

1 The name "Ukraine", which today exists on the designation of the state "Ukraine" and its territory, for several centuries was extraregional and not always associated with the name of a certain ethnic group. During the XV-XVII centuries the lands of Ukraine were in the administrative subordination of the Commonwealth and the Grand Duchy of Lithuania. The ethnic space of Ukraine itself became clear only in the middle of the XVII century, being identified with the Kyiv region, Chernihiv-Sivershchyna, Volyn', Podillya, and Galicia (see Yakovenko 1997). 
The authors of the research note the clarity and universality of the Latin language throughout the European area, the great expressive potential of Latin, which distinguished it favourably against the background of the only formed national languages. According to most researchers, all these qualities were possible only with the continuous development of the Latin language, its constant adaptation to changes in the life of society.

The millennial development of Latin brought some changes in spelling, morphology and syntax. It is worth remembering that in different regions of Europe, Latin was not homogeneous. This explains the emergence and development of so-called national dictionaries of medieval Latin, among them: Index scriptorum operumque LatinoBelgicorum medii aevi (Belgium), Dictionary of Medieval Latin from British sources, Medieval Latin world-list from British and Irish sources (Great Britain), Lexicon mediae Latinitatis Danicae (Denmark), Glossarium mediae Latinitatis Cataloniae (Spain), Latinitatis Italicae medii aevi ... lexicon imperfectum, Glossario Latino emiliano, Glossario latino italiano (Italy), Lexicon Latinitatis Nederlandicae medii aevi (the Netherlands), Mittellateinisches Wörterbuch, Mittellateinisches Glossar (Germany), Lexicon Latinitatis medii aevi Hungariae (Hungary), Latinitatis medii aevi Lexicon Bohemorum (former Czechoslovakia), Glossarium mediae Latinitatis Sueciae (Sweden), Lexicon Latinitatis medii aevi Iugoslaviae (former Yugoslavia), Glossarium Latinitatis medii aevi Finlandicae (Finland), Glossarium mediae et infimae Latinitatis, Lexicon Latinitatis medii aevi, Mediae latinitatis lexicon minus (France), Stownik Laciny Sredniowiecznej w Polsce (Poland). ${ }^{2}$ Despite the fact that most of these dictionaries began to be concluded in the second half of the XX century (and some earlier), for a variety of objective and subjective reasons (large volumes, heterogeneity and constant replenishment of the source base, socio-political changes, etc.), most of them remain incomplete.

Unfortunately, for a long time there was no specialized linguistic research devoted to the peculiarities of the Ukrainian literary monuments in Latin. Only in the second half of the XX studies began to appear dedicated to the linguistic interaction between Ukrainian and Latin, among which it is worth distinguishing those of N. Bezborod'ko (1972; 1978), S. Hrytsenko (2011; 2017), N. Korzh (1955; 1960), N. Yakovenko (1978; $1983 ; 1995 ; 1997)$. Despite a considerable volume of research on this issue, it should be noted that the root question of the majority of these works is the lexical analysis: the determination of ways and the establishment of historical sources of penetration of borrowings into the recipient language.

The question of the lexical composition of the medieval and of the early modern time Latin until now remains unresolved. The issues of the interference of the Polish-Ukrainian folk substrate with the Latin, which is manifested primarily in numerous borrowings and lexical tracing (word-building or semantic), and derivative models of neologisms, their grammatical features, and the ways of latinization of Ukrainian and Polish proper names, are insufficiently studied.

The object of the study is the lexical system of Latin on the territories of Ukraine of the $\mathrm{XV}-\mathrm{XVII}$ centuries. The subject of the research are common and specific features

2 See details Roelli (2009); Mantello (1996). 
of the lexical system of Latin language on the territories of Ukraine of the XV-XVII centuries.

The purpose of the study is to determine extra- and intralinguistic factors that influenced changes in the lexical system of Latin language on the territories of Ukraine of the XV-XVII centuries and to detect common and specific features of the lexical system of Latin language of the specified period.

The material of the study was a multi-genre variety of works of Ukrainian origin or Ukrainian-related works that could in general give an idea of the peculiarities of the Ukrainian regional variant of late Latin, in particular: the acts books (protocols) of the grodsky and zemsky courts of Galician Rus in nine volumes (Akta grodzkie i ziemskie z czasow Rzeczypospolitej Polskiej z Archiwum t.zw. Bernardynskiego we Lwowie: T. XI-XV, XIX); epic works (poem De bello Ostrogiano of Szymon Pękala); inscripts (about 1000 samples of Latin scripts represented by the card index of the Latin inscriptions of the XV-XVIII centuries from the territory of Ukraine collected during the field research in seven regions - Volyns'ka, Zakarpats'ka, Ivano-Frankivs'ka, Lvivs'ka, Rivnens'ka, Chernivets'ka, Khmelnyts'ka regions - and available in the works of Polish researchers of the $\mathrm{XIX}^{\text {th }}$ - beginning of $\mathrm{XX}^{\text {th }}$ centuries; Baraccz 1852, 1858; Czołowski 1892; Dzieduszycki 1872).

Unknown in the classical period realities of social life, that had to be described by the means of Latin language, could be both pan-European and narrow-territorial, characteristic only for a particular country or region. Every time it was necessary to describe a certain reality with a language, which was originally intended to function in another socio-cultural environment, immediately the question was arising regarding a possibility of transmitting by the means of this language the concepts and phenomena that were absent in the natural environment of this language. This question would appear before anyone who was using Latin language in the post-antique period, when for many centuries it had become a universal language of the European civilization.

Despite classical norms of Latin being the main benchmark in its use in the XV-XVII centuries, new elements were constantly penetrating the language, both due to the development of the language itself, as well as owing it to the contemporary language environment. This statement applies not only to neologisms, that are not recorded in the classical dictionaries, but also to the development of semantics of explicitly Latin vocabulary, considering that the new social realities were introducing adjustments not only to the matters of contemporary life, but also to the content of the vocabulary of that time.

Emergence of a large number of concepts describing new phenomena of social life in Ukraine in the XV-XVII centuries causes a need for a vocabulary for their designation. Consequently, new lexemes appear in the Latin language vocabulary of this specific period, or one can observe the development of traditional meanings of words of the classical Latin according to the needs of the new time.

The richness of word formation is one of the most significant features of Latin of the XV-XVII centuries. The authors postulated the rule of legitimacy for the use of Latin vocabulary of the non-classical period if it was used in the works of the so-called auctores 
probati. ${ }^{3}$ Classicus at that time meant not the belonging to the classical period, but rather the presence of certain language phenomena in the works of auctores probati. This view is confirmed by the data of Polish researchers, in particular, by Marian Plezia, who was among the first ones to study the vocabulary structure of the medieval and modern Latin in Poland. The researcher counted both the number of classical Latin words that did not find their continuation in Polish Latin, as well as the amount of new vocabulary that had not been recorded in the classical Latin. ${ }^{4}$

\section{Development of semantics of the classical Latin vocabulary}

One way of describing the unknown to classical Latin realities in their verbal designation by the means of Latin language is to select a Latin word with the value that is most closely related to the value of the non-equivalent unit. Thus, due to the emergence of new realities and the need for their linguistic expression, traditional for the classical period lexemes acquire a different semantic colour. In the Latin language of the XV-XVII centuries, the method of semantic enrichment finds its reflection, i.e. through expansion of the range of meanings of a classical Latin word, the content and volume of which largely depended on the territory where the text was written.

Development of semantics of the classical Latin vocabulary in Latin texts on the territories of Ukraine of the XV-XVII centuries evolves in two directions: 1) without changing the part-language paradigm, and 2) with the subsequent conversion (the substantiation of the adjective).

The development of semantics without changing the part-language paradigm is observed in:

a) military vocabulary: globus, $i \mathrm{~m}$ - sphere, globe > a round body, ball, sphere, globe: ... duobus globis trajectus (Dzieduszycki 1872: p. 61);

sclopus (=stloppus) - a slap, hit > musket: ... Ingentes scloppos per propugnacla fenestris / Intorquere ... (De bello III, 60);

siccarius (=sicarius), $i \mathrm{~m}$ - murderer, bandit > man of Zaporizhzhya Sich: Expulsus ferro cessit Siccarius urbe / Terectimirum... (De bello II, 13);

b) religious vocabulary: deus, i $m$ - a god, deity > Lord: Ita adjuvat me Deus... (Akta 1889: 218);

divinus, a, um - divine > of a god: ... divini honoris zelator (Barącz 1858: p. 103);

dominus, i $m$ - a master, lord > god: Pro iustis pugnat Dominus... (De bello I, 637);

c) vocabulary designating social status: baro, onis $m$ (only pl.tant. barones) - simpleton, mercenary > magnates: ... Caesareos inter Solem rutilare Barones... (De bello I, 44);

civis, is $m$ - a citizen, subordinated > townsman: Incredibile est omnium civium ... odium in dominum (Akta 1887: 557);

3 Benner (1977: p. 63).

4 Plezia (1969: p. 61). 
comes, mitis $m$ - a companion, friend > magnate: Venceslao Hyeronymo de Bogustawice comiti Sierakowski (Dzieduszycki 1872: p. 73);

consul, ulis - consul > assessor, raitsi - members of the election bourse for council of the magistrate: Zimorowicz consul (Dzieduszycki 1872: p. 26);

$d u x$, ducis $m$ - a leader, conductor > prince (duke), hetman; the complication of the social organization of society required establishment of compound terms incorporating $d u x$ to designate corresponding posts and occupations, cf. dux magnus - Grand Prince (Duke), dux supremus - Great Hetman, dux campester - Polny Hetman (deputy commander of the army): ... duce campestre Poloniae (Czołowski 1892: p. 107);... Russiacique Duces... (De bello I, 408);

scabinus, $i m$ - councilman, alderman (member of the court board), jury (scabinus, $i$ $m$ - the one sitting on the bench; scabillum, i $n$ - bench, footstool): ... scabinus Leopoliensis (Dzieduszycki 1872: p. 68);

palatinus, $i m$ - voivode (palatinus, $i m$ - the governor, the one who was in the service of the ruler): Stanislaus de Żotkiew palatinus Russiae ... (Dzieduszycki 1872: p. 18);

nobilitas, atis $f$ - nobles, aristocrats > szlachta, legally privileged noble class: Nobilitas haec prisca colit (De bello I, 202);

princeps, ipis $m$ - ruler, princeps > prince: Tu vero Ostrogios inter celsissime Princeps... (De bello IV, 188);

mareschallus, $i$ m - cavalry commander > marshalok - a public office position, the head of the noble confederation (with indication of the city of location), part of szlachta: ... Campi Mareschalci ... (Barącz 1852: p. 213);

d) other socio-political vocabulary: castrum, i $n$ - military camp, fortification > fortress, castle: Castra ruunt, muri quassantur (Baracz 1858: p. 132);

comitium, i n (only pl. tant. comitia) - commissions, assemblies, (pl.) people's meeting > sejm: Atque Duces, Regni Comitia multa loquuntur... (De bello I, 207);

stemma, atis $n$ - a garland, wreath; a degree, genealogical tree > coat of arms: ... Tum sua septingentis stemmata monstrat ab annis (De bello I, 264);

typus, i $m$ - a figure, imagin; fretwork > printing: ... Biblia sacra typis mandantur... (De bello I, 242).

The development of semantics with subsequent conversion (substantiation of the adjective) is observed in:

castellanus, i $m$ - castellan, chieftain < castellanus, a, um - of a fortification: Et procurator dicitur domino Castellano (Akta 1886: 1724);

serenissimus, $i m$ - fig. the clearest; his majesty < serenissimus, a, um - the clearest (від serenus, a, um - clear, gentle, calm): Serenissimus Joannes... (Dzieduszycki 1872: p. 64);

nobilis, is $m$ - nobleman, representative of szlachta < nobilis, $e$ - well-known, celebrated: Ukrainensi familia nobilissima genitus (Dzieduszycki 1872: p. 37);

capitaneus, $i m$ - chief in size; capitalis, $e-$ chief, eminent $\rightarrow$ the main, outstanding $\rightarrow$ complication of the social organization of society has led to the formation of compound terms from capitaneus to denote the corresponding posts, e.g. capitaneus exercituum Polny Hetman, capitaneus generalis - General Starosta (Elder, chief of staff): ... capitaneus fuit judicio de omnium melior... (Akta 1887: 1134). 


\section{Neologisms of Latin language of the XV-XVII centuries}

One of the characteristic features of Latin in the XV-XVII centuries, regardless of the territory of its distribution, is the formation of a large number of neologisms on the basis of the Latin vocabulary. In support of this view, one can quote the data of the Polish researcher K. Weyssenhoff-Brożkowa, ${ }^{5}$ according to whom approximately $25 \%$ of the vocabulary recorded in the not yet completed at that time Stownik Łaciny Sredniowiecznej w Polsce are neologisms, i.e. words that are not certified in any of the classical or medieval dictionaries (of other regions) of the Latin language.

The vocabulary undergoes not only rethinking; in many cases, new lexemes, as a rule suffixal, are formed to reflect new realities on the basis of words existing in the classical Latin. Creation of new words takes place in accordance with the rules of the word-formation of the classical Latin by means of word-forming affixes inherited from the Latin of classical period. Thus, the following types of neologisms are characteristic for the lexical spectrum of Latin works on the territories of Ukraine of the XV-XVII centuries:

1) neologisms, formed by means of suffixal derivation of classical Latin lexemes: a) by adding original Latin word-forming elements: -is: Constantinis - Constantine's < Constantinus, $i$ m - Constantine; -osus: mustosus - filled with wine < mustum, i $n$ - young wine; -ensis: Galiciensis (Haliciensis) - Galician < Galicia (Halicia), ae $f$ - Galicia; -inus: Taurinus - Taurian < Tauri, orum $m$ - tauri; -alis: Borealis - northern < Boreas, ae $m$ - Borea, fig. North; -bilis: extricabilis - exiled < extrico, àre - to disentangle, to look for, to get; b) by adding Latinised Greek word-formation elements: -i(a)des: Constantiniades - the descendant (son) of Constantine < Constantinus, i $m$ - Constantine; Palemonides - the descendant (son) of Palemonid < Palaemon, onis $m$ - Palemonid; -iss(a): haeredissa, ae $f$ - heiress < heres, edis $m, f$ - heir, -ess; ducissa, ae $f$ - hetman's wife, princess < dux, ducis $m$ - leader; -tudo: gratitudo, inis $f$ - unselfishness < gratuitus, a, um - unselfish; -lar: tutelar, aris $n$ - guard < tutelaris, $e$ - protective;

2) neologisms, formed by compositions of classical Latin lexemes of Greek origin, for example: Leontopolis - Lviv < leo, onis $m$ - lion, leonticus, a, um - lion's and -polis; Olbipolis - Olbia < Olbia, ae f-Olbia and -polis; tapefactum < tapes, etis $m$ and tapetum, i $n$ - carpet, blanket; zelosissimus, a, um - the most zealous < comp. Greek ó $\zeta \tilde{\eta} \lambda$ o - zeal, diligence;

3) neologisms, created by borrowing Greek lexemes, for example: Biblia - Holy Script

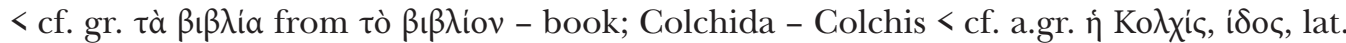

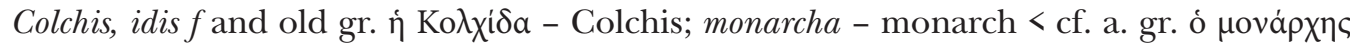
- the sole ruler and lat. monarchia, ae $f$ - omnipotence; patriarcha - ancestor, founder

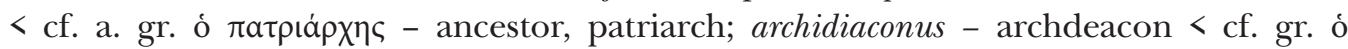

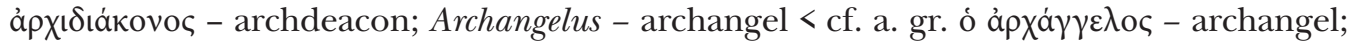
episcopus, $i m$ - bishop and episcopatus, $i m$ - higher clergy; the system of church govern-

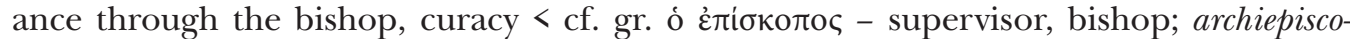
pus, $i m$ - highest bishop and archiepiscopatus, $i m$ - higher clergy; the system of church

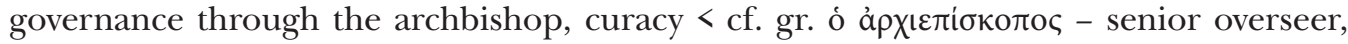

$5 \quad$ Weyssenhoff-Brożkowa (1998: p. 87). 


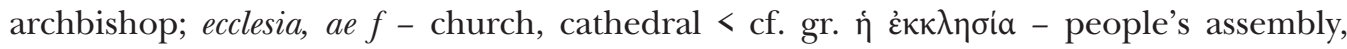
church; presbyter, eri $m$ - priest, presbyter; presbyterium, ii $n$ - room in the church, sacristy $<$ cf. gr. o $\pi \rho \varepsilon \sigma \beta \dot{\tau} \tau \eta \varsigma$ - the elder; metropolis, is $f$ - residence of the Metropolitan < cf. gr. $\dot{\eta}$

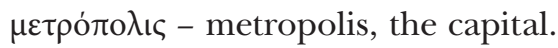

\section{Word-forming adaptation of foreign language vocabulary}

For Latin of the XV-XVII centuries, which had a flexible linguistic system with strong grammar and lexical basis, preserved from the classical Latin, the lexical eclecticism was characteristic due to the presence of a large number of foreign-language inclusions of different-time origin. These elements, caused by the need to describe new life realities, reflected both intralingual development of the Latin language, as well as the influence of other languages.

Thus, in Latin works on the territories of Ukraine of the XV-XVII centuries, a significant volume of foreign language vocabulary of different origins is recorded, the analysis of which is complicated not only by the absence of special lexicographic sources of Latin in the investigated period, but also by inconsistency of the information provided in the existing ones. Therefore, one can only assume with a greater or lesser probability which of the lexemes selected by the author were commonly used in the Latin language of that time, and which can be considered as authors' occasionalisms.

Mastering of borrowings takes place on different levels of the language system, among which lexical-semantic and word-forming levels constitute higher degrees of assimilation of lexical borrowings, the basis of which is graphic, phonetic, morphemic adaptation. Thus, the study of the adaptation of borrowings to the morphemic and word-forming subsystems of Latin language entails identifying peculiar features of assimilation of borrowings by the word-formation subsystem of the recipient language.

Among the main ways of using foreign language vocabulary in Latin works on the territories of Ukraine of the XV-XVII centuries, it is possible to distinguish two main tendencies: the use of the Latin lexical spectrum of the XV-XVII centuries, and the use of authors' occasionalisms. The boundary between these groups, due to the lack of complete or at least partial ${ }^{6}$ lexicographic record of lexical composition of the Latin language of that time, is only hypothetical. Therefore, the study does not aim at determining the time and sources of penetration of borrowings into the recipient language, but merely attempts to identify possible patterns of assimilation and to establish the factors that influenced the degree of assimilation of the borrowed vocabulary and resulted in their full or partial adaptation into the phonetical-orthographic and lexical-grammatic levels of the Latin language.

The time of appearance of the represented borrowed vocabulary in Latin works on the territories of Ukraine of the XV-XVII centuries can only be arbitrarily regarded as

6 In the existing (although limited in number) lexicographic sources of medieval and modern Latin, as a rule, the detailed information regarding the time of assimilation of a foreign language element is not provided. 
a time of borrowing, considering that the fixed lexemes could have existed in Latin of previous periods long before the creation of the examined works. In addition, the majority of borrowed vocabulary recorded in Latin texts on the territories of Ukraine of the XV-XVII centuries are to some extent "author's/copyright" borrowings, and therefore do not fully reflect the use of the language of that time.

The lack of sufficient lexicographic and factual material does not allow to assert the ways of penetration of borrowed vocabulary; we can only assume that the authors could in some cases use the ready-made samples of the adapted vocabulary, while in other cases the author's neologisms were created.

In the use of borrowed vocabulary research, one of the most difficult issues has always been the delineation of concepts that denote this kind of vocabulary. In linguistic literature, different terms are used to designate this kind of vocabulary: "foreign words, borrowings, barbarisms", etc. The most common term to refer to words that come in from another language is the "loanwords". In the majority of cases, it denotes both the linguistic process of borrowing and the results of this process.

The following thematic groups from the examined texts can be identified as belonging to the foreign-language or partly Latinized vocabulary, uncharacteristic for the classical period:

Nouns: a) ethnonyms: Basarabaei, Lithavus, Moschus, Ruthenus, Valachus, Cosaci; b) toponyms: the names of cities and towns: Terectimirum, Ostrogia, Comenca, Halicia, Tharnava, Sieniavia, Batoho; names of countries and regions: Volinia, Podolia, Chortica; river names: Trubesi, Techina, Slucus, Icqua, Horinus, Boliyanovka; names of inhabitants: Ostrogios, Nisovius; c) surnames and nicknames: Chaidar, Iarmolinscius, Kosinscius, Nossus, Polochus, Zavacius, Socha, Kysel, Lisowski, Popel, Boim, Krasicki; d) proper names of people, historical or mythological figures: Batthus, Bochdanus, Ianusius, Ichor, Mecislaus, Svidrigellus, Wlodimire, Jacz, Hriszko, Iwan, Sigismundus; e) patronyms: Olgerdoviades, Ioanniades, Lechiades; f) other common names: mecith, tabor, ulani, baeran, Catholicus.

Adjectives: a) derived from toponyms: Drucensis, Ostrogius, Sluccensis, Socalensis, Trebolensis, Galiciensis, Korsunensis, Kijoviae; b) derived from ethnonyms: Turcicus, Russica, Polonus, Lithavae, Ukrainensi; c) derived from proper names: Wladimiria, Rurconis, Lubarciacos, Ostrogiorum.

By origin and type of foundations, the foreign-language vocabulary can be structured into the following groups: a) Slavic-originated, e.g.: Bochdanus, Dobeslaus, Stanislaus; b) orientalisms, e.g.: Batthus, mecith, baeran; c) Germanic-originated, e.g.: Borussus, Volsthen, Vitoldi, Fridro, Albertus, Ferdinandus, Henrico, Groswajer, Hermanus; d) Greek-originated, e.g.: Andreae, Basili, Theodor, Theodora, Katherina (Catharina), Leopolim, Hyeronymo, Demetrius, Christophori, Strophio, Stephano.

Despite the fact that the borrowed vocabulary recorded in Latin works on the territories of Ukraine of the XV-XVII centuries is structurally heterogeneous, nevertheless the following types of the borrowed vocabulary can be distinguished in it: a) vocabulary that structurally coincides with the foreign-language prototype, i.e. words that are graphically modified and transmitted by appropriate phonetic means of the Latin language without any structural changes; b) vocabulary that is morphologically executed by means of 
the Latin language, including a vocabulary with a partial word-forming substitution (in most cases the affixal part is substitutable/substituted). Thus, due to different degrees of word-forming adaptation, ${ }^{7}$ foreign language vocabulary can be divided into two different groups.

Borrowed vocabulary, which is characterized only by phonetic and graphic adaptation, the essence of which lies in the transfer of phonetic and graphic image of a foreign word using graphic means of the recipient language, for example: baeran, mecith, tabor, Ichor, Zaręba, Techina, Czapliczowna, Kamien, Milewski, vladikas, kmethones.

The Latin language of the examined texts reflects common at that time tradition of transferring borrowed vocabulary into the transliterated forms, i.e. the transfer of loanwords is done using Latin graphics while preserving the phonetic and grammatical features of the original.

The absence of the morphological adaptation of such a vocabulary can be explained by the lack of need for other case forms, except for those used in the texts in nominative case in the function of subject, or in accusative case of neuter gender of direct object, which according to the rules of Latin morphology is always equal to the nominative form.

Borrowed vocabulary, characterized by morphological adaptation, which entails inclusion of loanwords into the system of gender, number and declination, etc. This adaptation, on the level of morphology, is achieved by joining the phonetically and graphically adapted Slavic stem word with the Latin or Latinized Greek formant-flexion, the appearance of which means belonging to a specific grammatical category and is an indicator of a certain degree of assimilation of loanwords within the Latin language.

For the large part of this vocabulary, there is a characteristic partial word-forming substitution, which is achieved by means of suffixal derivation via joining the phonetically and graphically adapted Slavic stem words with the Latin or Latinized Greek wordforming affix in conjunction with flexion. A large number of adapted Slavic proper names recorded in the poem allows them to be arranged into several groups. ${ }^{8}$

Nouns with formants $-a$ and - $i a$, morphologically adapted by the type of Latin feminine or masculine nouns of the first declension. As a rule, such phonetic-morphological adaptations pertain to the Slavic toponyms ending with - $a$, - анъ, - инъ, that are typical not only for female gender, for example: Kazna, Volinia, Tyram, but also for masculine with a termination on consonant, as well as neutral ending with - $o$ and $-\Omega$, that are formally associated with the Latin terms urbs and terra: Turovia, Czudna, Sedomiria, Ostrogia, Halicia (Galicia), Dubna, Podolia, Tharnava, Pelkam, Sieniavia.

Nouns with formants -us, -ius, -um, morphologically adapted by example from the Latin masculine and neutral nouns of the second declension. Phonetic-morphological

7 By the term "word-forming adaptation" it is meant the assimilation in the language of the original borrowing by maximizing its phonetic, graphic, grammatical and lexical-semantic characteristics to the corresponding norms of the recipient language.

8 The given classification is based mainly on formal characteristics of borrowed words. 
adaptations by means of a formant - us are attributed, as a rule, to the Slavic or Slavonic ethnonyms, toponyms and proper names and surnames. For instance: ethnonyms with a stem of consonant: Valachus, Lithavus, Borussus, Ruthenus, Cosacis, Moschorum; proper names ending with -слав, -мир, -ан, -ин and other endings: Dobeslaus, Mecislaus, Wlodimire, Semerinus, Vitoldi, Onuphrius, Machometi, Batthus, Stecyzko, Schamlorium; surnames: Polochus, Nossus, Koributus, Campiani, Domagalicius, Dybovicius; toponyms: Horinus, Slucus, Trubesi.

With the help of the Latin formant -ius, primarly Slavic or Slavonic surnames ending with -цъкий, -съкий, are adapted, for example: Zavacius, Visnovecius (Visniovieccius), Iarmolinscius, Kosinscius, Zachorovius, Zamoscius, Leszczynius, Radziwillius and sporadically, other proper masculine names, for example: Ianusius, Ostrogius.

The formant -um serves for the word-formation of Slavic nouns, usually in designation of cities, for example: Ostrogium, Piatcum, Smolenscum, as well as regions: Cremum.

Nouns with the formant -o (Gen. Sg. -onis), morphologically adapted according to the type of Latin masculine nouns of third declension. In this group, most nouns can be enlisted only hypothetically, since they are found in the text in indirect cases, for example: Iagellonem, Miesconis, Rurconis, Costconem, Ivankonem, Steczkonis, kmetho, kmethonis.

Adjectives with formants -us $(-a,-u m)$ and $-i u s(-a,-u m)$, morphologically adapted by the type of Latin adjectives of first and second declension ending with -us, -a,-um. According to this example, as a rule, are adapted adjectives originated from ethnonyms and toponyms; occasionally, also adjectives derived from male names. For examples: Lithavus, Polonus, Kijoviae, Ostrogiorum, Oginscia.

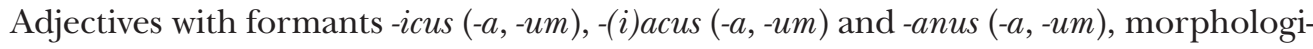
cally adapted by the type of Latin adjectives of first and second declension. The following adjectives can be attributed to this type: Voliniacus, Russiacus, Ostrogianus, Preclaviana, turcica, Kossakowsciana, Danilowicciana, that, similarly to the previous group, are originated from toponyms, ethnonyms and male proper names.

Adjectives with the formant -ensis (-e), morphologically adapted by the type of Latin adjectives of third declension. This word-forming type is recorded only in the group of adjectives originated from toponyms, for instance: Sluccensis, Socalensis, Trebolensis, Volinensis, Korsunensis, Chioviensis (Kijoviensis), Stanislaopoliensis, Ukrainensi, Javoroviensis.

Nouns with the Latinized Greek formants -ades and -adis, morphologically adapted by the type of Latin masculine nouns of third declension, for examples: Olgerdoviades, Lechiades, Ioanniades.

Nouns with the Latinized Greek formants -is, -as, -es morphologically adapted by the type of Latin masculine and feminine nouns of third declension. This group of neologisms can include the following nouns: Ostropolis, Corsunis, Ioannis, Helias, Andreae, Johannes, Leopolim, Joannes.

Adjectives with the Latinized Greek formants -idis and -eus, morphologically adapted by the type of Latin adjectives of second and third declension accordingly. The following adjectives can be attributed to this type: Horinides, Vilgiadas, Ostrogeus. 


\section{Conclusions}

Changes in the lexical composition of the Ukrainian regional variant of the XV-XVII centuries occur in three directions - the change in the meaning of the specific Latin vocabulary, the emergence of neologisms, formed from the lexical foundations of classical Latin, and word-building adaptation of vocabulary borrowed from other languages.

The following tendencies are typical for the change in the meaning of the specific Latin vocabulary: expansion of semantic volume (generalization), narrowing of lexical meaning (specialization) and the emergence of a new meaning.

The creation of new words takes place in accordance with the rules of the word-formation of classical Latin by derivation and composition with the help of Latin or Latinized Greek base words and word-formation affixes inherited from the Latin classical period.

Among the main methods of word-formation adaptation of the foreign language vocabulary in the Ukrainian regional variant of the Latin of XV-XVII centuries, three tendencies can be distinguished: transliteration, morphological adaptation and suffixal derivation with the support of Latin or Latinized Greek word-building formants, which were added to foreign-language base words.

A small number of morphologically unadapted words, which are used only in the nominative order, and the presence of morphologically adapted in this and all other grammatical positions, testify to the conservatism of the authors, one of the manifestations of which is the use of the traditional word-formation system of the Latin language in the principle of an analogous word-formation, that is, the formation of parallel forms by analogy. The presence of word-forming doublets can be qualified as a manifestation of speech dynamics, which is most characteristic of the lexical level of speech. The derivativeness variability is determined both by intra- and extra-linguistic factors. The models of derivational variability associated with the internal structure of the word-formation system are of a constant value, and the content of these models is a reflection of speech dynamics.

Frequent use of proper names (both specifically Latin and borrowed) in the Ukrainian regional version of Latin of the XV-XVII centuries testifies not only the adherence by the authors of the generally accepted since the ancient times practice, according to which their own names were used as an indicator of a close acquaintance with a particular material, but also of a peculiar emphasis of the cautious wisdom of authors, especially in the case of word-formation adaptation of borrowed ethnonyms and toponyms.

The means used by the authors to transmit the new realities of life, in particular the expansion of the semantic volume of a word, the use of neologisms and word-formation adaptation were common for the Latin language in Ukraine in XV-XVII centuries.

The presented below results and conclusions may serve as the basis for conducting new research on the problems of functioning of the Latin language on the territory of Ukraine and, generally, Eastern Europe in the XV-XVII centuries, since the question of the lexical composition of Latin for this period remains unresolved. 


\section{Bibliography}

Akta grodzkie i ziemskie z czasów Rzeczy Pospolitej Polskiej z Archiwum t. zw. Bernardyńskiego we Lwowie. (1886-1889, 1891, 1906). (T. XI-XV, XIX). Lwów.

Axer, J. (1991). Polski teatr jezuicki jako teatr polityczny. In J. Axer, Filolog w teatrze (pp. 99-109). Warszawa: PAN.

Axer, J. (1995). "Latinitas” w historii i pamięci historycznej Europy Środkowo-Wschodniej. Paradoksy ciągłości i nieciągłości. In J. Axer (Ed.), Zeszyty Naukowe, 1-2: Między Slavia Latina i Slavia Orthodoxa (pp. 81-89). Warszawa: OBTA.

Barącz Sadok, W. (1852). Pamiatki miasta Żotkwi. Lwów: Piller.

Barącz Sadok, W. (1858). Pamiątki miasta Stanistawowa. Lwów: Ossolineum.

Benner, M. (1977). On the interpretation of learned Neo-Latin: an explorative study based on some texts from Sweden 1611-1716. Göteborg: Acta Universitatis Gothoburgensis.

Bezborod'ko, N. I. (1972). Latyn' XVII veka kak yazykovaya problema. Voprosy istorii i metodiki prepodavaniya inostrannyh yazykov, 3, 3-6.

Bezborod'ko, N. I. (1972). Opredelitel'nye predlozheniya s ottenkami v latinskom yazyke 17-go veka (na materiale „Metafizicheskogo traktata” I. Gizelya). Voprosy istorii i metodiki prepodavaniya inostrannyh yazykov, 3, 80-89.

Bezborod'ko, N. I. (1972). Yazyk latinskih traktatov ukrainskih filosofov XVII veka. Dnepropetrovsk.

Bezborod'ko, N. I. (1978). Uchenaya latyn' na Ukraine. Voprosy yazykoznaniya, 6, 85-92.

Czołowski, A. (1892). Dawne zamki i twierdze na Rusi halickiej (Teka konserwatorska; pp. 65132). Lwów: Nakł. Koła C. K. Konserwatorów.

De bello Ostrogiano ad Piantcos cum Nisoviis libri quattuor, a Simone Pecalidis Artium Baccalaureo conscripti (1600). Cracoviae: In officina Andreae Petricovii.

Dorovskih, L. V. (1987). Ob upotreblenii predlogov pozdnej latyni (na materiale hroniki vengerskogo Anonima). Yazyk i stil' pamyatnikov antichnoj kul'tury, 46-55.

Dorovskih, L. V. (1997). Infinitiv v srednevekovoj latyni: (na materiale hroniki vengerskogo Anonima). Voprosy indoevropejskogo slovoobrazovaniya $i$ klassicheskoj filologii: Sbornik statej pamyati G. M. Shatrova, 124-132.

Dorovskih, L. V. (1997). Ob obrazovanii narechij v srednevekovoj latyni: (na materiale hroniki vengerskogo Anonima). Voprosy indoevropejskogo slovoobrazovaniya i klassicheskoj filologii: Sbornik statej pamyati G. M. Shatrova, 114-124.

Drboglav, D. A. (1993). Uchebnoe posobie po srednevekovoj latyni. Moskva: MGU.

Dzieduszycki, M. N. (1872). Kościót katedralny lwowski obrz. tacińskiego pod wezw. Wniebowzięcia Najśw. Panny. Lwów: Nakł. Hołyńskiego.

Evans, M. (1995). Basic grammar for medieval and renaissance studies. London: Warburg Inst., Univ. of London.

Hammarström, M. (1925). Glossarium till Finlands och Sveriges Latinska Medeltidsurkunder jämte språklig inledning. Helsingfors: Finska Litteratur Sällskapets Try.

Hrytsenko, S. P. (2011). Leksychni latynizmy v ukrainskomovnykh tekstakh kin. XVI-XVII st. Kyiv: VPTs „Kyivskyi universytet”.

Hrytsenko, S. P. (2017). Dynamika leksykonu ukrainskoi movy XVI-XVII st. Kyiv: KMM. 
Korzh, N. G. (1955). Mesto i osobennosti latinskogo yazyka v tvorchestve G. S. Skovorody. Avtoref. dis. ... kand. filol. nauk, Har'kov.

Korzh, N. G. (1960). O nekotoryh leksicheskih osobennostyah latinskogo yazyka G. S. Skovorody. Trudy filologicheskogo fakul'teta Har'kovskogo gosuniversiteta im. M. Gor'kogo, 8, 11-24.

Langosch, K. (1983). Lateinisches Mittelalter: Einleitung in Sprache und Literatur (4th ed.). Darmstadt: Wissenschaftliche Buchgesellschaft.

Lehmann, P. (1911). Einleitung in die lateinische Philologie des Mittelalters. München: C. H. Beck.

Luc'ka-Litvyak, F. I. (1960). Iz istorii latinskoj social'no-politicheskoj leksiki. Trudy filologicheskogo fakul'teta HGU im. M.Gor'kogo, 8, 201-211.

Mantello, F. A. C., \& Rigg, A. G. (1996). Medieval Latin: An Introduction and Bibliographical Guide. Washington DC: Catholic University of America Press.

Marouzeau, J. (1922-1953). L'ordre des mots dans la phrase latine. Paris: Les Belles Lettres.

Marouzeau, J. (1943). La prononciation du latin (histoire, théorie, pratique). Paris: Les Belles Lettres.

Nechutová, J. (2002). Středověká latina. Praha: Koniasch Latin Press.

Norberg, D. (1959). Remarques sur l'histoire de la prononciation du latin. Acta Conventus Romani, 107-114.

Norberg, D. (1980). Manuel pratique du latin médiéval. Paris: Picard.

Plezia, M. (1969). Structura słownictwa łaciny średniowiecznej na podstawie II tomów Słownika Łaciny Średniowiecznej. Sprawozdania z posiedzeń komisji naukowych PAN, 59-61.

Roelli, Ph. (2009). Einführung ins Studium der Lateinischen Sprache und Literatur des Mittelalters: Bibliographien und kurze Einführungen. Zürich: Universität Zürich.

Stownik Łaciny Średniowiecznej w Polsce (1953-). [Ed. Polska Akademia Nauk]. Wrocław: ZNiO.

Stotz, P. (1996-2004). Handbuch zur lateinischen Sprache des Mittelalters (5 vols.). München: C. H. Beck.

Strecker, K. (1939). Einführung in das Mittellatein. Berlin: Weidmann.

Vidmanová, A. (1969). K výslovnosti a grafice středověké latiny w Čechách. Listy filologické, 92, 294-300.

Weyssenhoff-Brożkowa, K. (1998). Studia nad tacina średniowieczna w Polsce. (Zesz. 10-12). Warszawa: OBTA.

Yakovenko, N. (1997). Narys istorii Ukrainy z naidavnishykh chasiv do kintsia XVIII st. Kyiv: Heneza.

Yakovenko, N. M. (1978). Peredumovy poshyrennia i kharakter latynskoho pysma na Pravoberezhnii Ukraini: druha polovyna XVI - persha polovyna XVII st. Arkhivy Ukrainy, 6, 8-19.

Yakovenko, N. M. (1995). Sotsialna terminolohiia latynskoho dokumenta ukrainskoho pokhodzhennia XIV-XVI st. Inozemna filolohiia: Mizhvidomchyi naukovyi zbirnyk, 80, 85-89.

Yakovenko, N. M. (1997). Latynske shkilnytstvo i „shkilnyi humanizm” v Ukraini kintsia XVI - seredyny XVII st. Kyivska starovyna: naukovyi istoryko-filolohichnyi zhurnal, 12, 11-27.

Yakovenko, N. N. (1983). Paleografiya latinskogo dokumental'nogo pis'ma na Pravoberezhnoj Ukraine. Avtoref. ... kand. istor. nauk, Kiev.

Ph.D. (Philology), associate-professor Valentyna Myronova / myronova63@gmail.com

Department of General Linguistics, Classical Philology and Neohellenistic Studies 
Taras Shevchenko National University of Kyiv, The Institute of Philology

14 Taras Shevchenko Blvd., 01601 Kyiv, Ukraine

Ph.D. (Philology), associate-professor Nataliia Korolova / kardeadea@gmail.com

Department of General Linguistics, Classical Philology and Neohellenistic Studies

Taras Shevchenko National University of Kyiv, The Institute of Philology

14 Taras Shevchenko Blvd., 01601 Kyiv, Ukraine

Ph.D. (Philology), associate-professor Oksana Koshchii / oksanak@bigmir.net

Department of General Linguistics, Classical Philology and Neohellenistic Studies

Taras Shevchenko National University of Kyiv, The Institute of Philology

14 Taras Shevchenko Blvd., 01601 Kyiv, Ukraine 
